\title{
Misi Penginjilan Pada Masa Penciptaan dan Masa Kini
}

\author{
Desi Natalia \\ Institut Agama Kristen Negeri Palangka Raya \\ desi.nataliaahad@gmail.com
}

\begin{abstract}
The mission of evangelism at the time of creation in the biblical text of Genesis 1 and the mission of evangelism at this time, especially at GKE Hosianna Palangka Raya explain the two contexts that have colorful cultures, so that they require contextual stages, so that the mission of evangelism can be achieved. The method used is a qualitative method with a descriptive narrative approach, and uses an interpretive paradigm. Sources of data from interviews and literature studies related to evangelistic missions, the time of creation, and the present. The results showed that the congregation's space and time were limited in the use of the Ngaju Dayak language liturgy both in its implementation and service implementation, so that the implementation of this liturgy was increasingly marginlized and it was necessary to make more innovative evangelistic strategies in responding to the covid-19 pandemic and after the covid-19 pandemic. The positive impact is being able to reduce the potential for the spread of covid-19, so that God's relationship between family members becomes harmonious.
\end{abstract}

Keywords: evangelism mission; the time of creation; present time

\begin{abstract}
Abstrak
Misi penginjilan pada masa penciptaan dalam teks Alkitab Kejadian 1 dan misi penginjilan pada masa kini, khususnya di GKE Hosianna Palangka Raya menerangkan kedua konteks yang memiliki kebudayaan yang berwarna-warni, sehingga memerlukan tahapan kontekstual, agar misi penginjilanpun dapat tercapai. Metode yang digunakan yaitu metode kualitatif dengan pendekatan deskriptif-naratif, serta menggunakan paradigma interpretatif. Sumber data dari hasil wawancara dan kajian literatur yang berkaitan dengan misi penginjilan, masa penciptaan, dan masa kini. Hasil penelitian menunjukkan ternyata ruang dan waktu jemaat menjadi terbatas dalam penggunaan liturgi bahasa Dayak Ngaju baik dalam pelaksanaan maupun pelaksana pelayanannya, sehingga penyelenggaraan liturgi ini semakin terpinggirkan dan perlu membuat strategi penginjilan yang lebih inovatif dalam menyikapi masa pandemi covid-19 dan setelah masa pandemi covid-19. Dampak positifnya yaitu mampu mengurangi potensi penyebaran covid-19, sehingga jemaat Tuhan dapat dalam keadaan sehat dan hubungan antara anggota keluarga menjadi harmonis.
\end{abstract}

Kata Kunci: masa kini; masa penciptaan; misi penginjilan 


\section{Pendahuluan}

Misi penginjilan telah terjadi mulai dari masa penciptaan hingga masa kini. Dalam perjalanan waktu yang tidak begitu singkat ini, tentunya ada proses dan perubahan dalam melaksanakan misi penginjilan ini, jika dilihat dari sisi kebudayaannya. Sebab masing-masing warga mempunyai kebudayaan yang beragam. ${ }^{1}$ Dalam teks Kejadian 1 masa penciptaan diwarnai penyampaiannya dari bahasa Ibrani dan pemikiran Yunani ${ }^{2}$ yang pada akhirnya mempunyai pengaruh dalam memberi ketentuan yang amat tersampaikan akan tujuan Tuhan kepada umatnya. Sebagaimana yang dikatakan oleh J. Andrew bahwa para penulis Alkitab menggunakan kebudayaan untuk mengkomunikasikan cerita atau keterangan mengenai kejadian atau peristiwa itu. ${ }^{3}$ Mereka sekali-sekali meminjam dari kebudayaan lain, misalnya, binatang laut raksasa yang disebut Lewiatan, berasal dari kebudayaan Babel (Mzm. 104:26; Ayb. 3:8; 41:1); perjanjian Allah dengan umatNya yang menggambarkan wujud perjanjian bangsa Het dengan bangsa-bangsa yang sudah mereka taklukkan, dan banyak bagian dari Kitab Amsal mempunyai padanan dalam kebudayaan-kebudayaan lain.

Konteks pandemi covid-19 pada masa kini, yakni adanya pendekatanpendekatan dipandang perlu menurut gerak kebutuhan dan keadaan kebudayaan masyarakatnya yang banyak ragamnya, sehingga dibutuhkan rencana yang cermat mengenai kegiatan untuk mencapai sasaran khusus dalam penginjilan. Hal ini sebagaimana juga yang telah dikatakan oleh Sugiono bahwa usaha yang mengena untuk mengungkapkan keterangan dengan perkataan mengenai kejadian atau peristiwa kabar baik kepada masyarakat yang terdiri atas beberapa bagian yang merupakan kesatuan pada saat ini, yakni melalui tahap kontekstualisasi. ${ }^{4}$ Misalnya, di Indonesia yang terdiri dari berbagai suku bangsa yang tak sama, tetapi masingmasing kebudayaan mempunyai ciri atau sifat yang sama. Bangsa Indonesia mempunyai alat pemersatu dari banyak ragam budaya, suku dan bahasa daerah yaitu bahasa Indonesia yang berasal dari bahasa Melayu. Hal ini dilihat dari banyak macam budaya, suku dan bahasa daerah yang ada di Indonesia. ${ }^{5}$ Kemudian kultur/budaya ini dikembangkan sedemikian rupa oleh manusia menjadi tatanan yang established dalam bentuk institusi, sehingga budaya (sebagai institusi) mampu menarik masuk hingga meresap dan menjadikan manusia sebagai bagian dari kebudayaan itu sendiri (misalnya: agama, seni, dan lain-lain). ${ }^{6}$ Unsur-unsur kebudayaan tersebut merupakan rangkaian pengembangan dan saling menambah sesuatu yang kurang, supaya menjadi lengkap antara satu dengan yang lainnya

\footnotetext{
${ }^{1}$ Ridwan Effendi Elly M. Setiadi, H. Kama A. Hakam, Ilmu Sosial Dan Budaya Dasar, 8th ed. (Jakarta: Prenada Media Group, 2012).

2 D.A. Hubbars dan F.W. Bush W. S. LaSor, Pengantar Perjanjian Lama 1: Taurat Dan Sejarah, 17th ed. (Jakarta: Gunung Mulia, 2012).

3 J. Andrew Kirk, Apa Itu Misi? Suatu Penelusuran Teologis (Jakarta: Gunung Mulia, 2012).

${ }^{4}$ Panjhi Sugiono, "Pendekatan Penginjilan Kontekstual Paulus Berdasarkan Kisah Para Rasul 17:16-34," Jurnal Ilmu Teologi dan Pendidikan Agama Kristen 1, no. 2 (2020): 87.

5 Tio Pilus Arisandie, "Potret Kekristenan Pada Suku Dayak Pesaguan Di Provinsi Kalimantan Barat," Jurnal Ilmiah Religiosity Entity Humanity (JIREH) 3, no. 1 (2021): 63-75.

${ }^{6}$ Firman Panjaitan and Hendro Siburian, "Misi Kristologi Dalam Konteks Kebudayaan," Logia 1, no. 1 (2020): 44-61.
} 
dengan menyebarkan Injil melalui saluran komunikasi akan lebih sesuai bersapa dengan konteks budaya masyarakat. Hal tersebut menunjukkan perlawanan yang kuat antara Injil dan kebudayaan dapat dikaitkan, bahkan dapat menjadi media pemberitaan Injil yang efektif. ${ }^{7}$ Bagian ini pula yang seharusnya diperhatikan dalam pelaksanaan misi penginjilan di Gereja Kalimantan Evangelis (GKE) Hosianna Palangka Raya.

GKE Hosianna Palangka Raya merupakan salah satu GKE yang ada di kota Palangka Raya. GKE merupakan sebuah badan atau organisasi gereja yang telah berkarya di bumi Kalimantan berpuluh-puluh tahun lamanya, bahkan telah lama dari usia Negara Indonesia. ${ }^{8}$ Misi penginjilan pada seluruh penjuru Kalimantan yang menjadi bagian Indonesia merupakan ladang tugas kewajiban cara melayani GKE. Gereja ini sebagai suatu lembaga yang disusun baik-baik oleh peraturan yang secara resmi dianggap mengikat. Gereja yang merupakan persekutuan orang percaya (eklessia) menghimpun orang-orang seiman yang percaya kepada Yesus Kristus. $^{9}$

Penelitian sebelumnya hanya menyajikan sistem kepercayaan orang Dayak Bakati. ${ }^{10}$ Potret Kekristenan pada suku Dayak juga pernah dilakukan dalam penelitian. ${ }^{11}$ Berikutnya, penelitian tentang pemberitaan Injil kepada suku Dayak Bumate hanya sebatas korban pencurahan darah binatang. Hal yang menarik dari penelitian ini dibandingkan penelitian-penelitian terdahulu yaitu tentang misi penginjilan pada masa penciptaan dalam teks Alkitab Kejadian 1 dan misi penginjilan pada masa kini, khususnya di GKE Hosianna Palangka Raya yang pada masing-masing kedua konteks tersebut memiliki kebudayaan yang berwarna-warni yang turut serta mempengaruhi misi penginjilan. Dengan kata lain, adanya pendekatan-pendekatan bermacam-macam yang digunakan sesuai dengan keperluan dan konteks keadaan warganya, baik dari pada masa penciptaan maupun pada masa pandemi covid-19 dibutuhkan tahapan kontekstual, sehingga misi penginjilanpun dapat tercapai.

\section{Metode Penelitian}

Kajian tentang misi penginjilan pada masa penciptaan dalam teks Alkitab Kejadian 1 dan misi penginjilan pada masa kini, khususnya di Jemaat GKE Hosianna Palangka Raya dalam tulisan ini menggunakan metode kualitatif. Metode kualitatif menurut Kirk dan Miller (1986:9) dalam tulisannya Helmuth Y. Bunu yaitu adat kebiasaan turun-temurun (dari nenek moyang) yang masih dijalankan dalam masyarakat tertentu dalam ilmu pengetahuan sosial yang secara mendasar terkait dengan observasi pada manusia baik dalam daerah tertentu yang mempunyai ciri

${ }^{7}$ David Eko Setiawan, “Menjembatani Injil Dan Budaya Dalam Misi Melalui Metode Kontektualisasi," Fidei: Jurnal Teologi Sistematika dan Praktika 3, no. 2 (2020): 160-180.

${ }^{8}$ Marko Mahin, 70 Tahun GKE: Pergumulan Dan Upaya GKE Menuju Kemandirian (Banjarmasin: Majelis Sinode Gereja Kalimantan Evangelis, 2005).

9 Firman Christian and Robi Panggarra, “Makna Kata Ekklesia Berdasarkan Matius 16:18 Dan Implementasinya Dalam Kehidupan Orang Percaya Masa Kini," Jurnal Jaffray 9, no. 2 (2011): 90.

${ }^{10}$ Kokos Kosmanto, "Strategi Penginjilan Kontekstualisasiterhadap Kebudayaan Gawai Dayak Bakati Di Kiung" (2020).

${ }^{11}$ Arisandie, "Potret Kekristenan Pada Suku Dayak Pesaguan Di Provinsi Kalimantan Barat." 
tertentunya maupun dalam kata atau ungkapan khususnya. ${ }^{12}$ Peneliti juga melakukan wawancara tidak berstruktur untuk menemukan perubahan baik dari segi bahasa sampai pendekatan yang digunakan oleh GKE Hosianna pada masa pandemi covid-19. Penulis juga menggunakan pendekatan deskriptif-naratif dengan paradigma interpretatif sebagai salah satu maksud yang digunakan dalam cara kualitatif (alamiah). ${ }^{13}$ Adapun pendekatan deskriptif-naratif ini yang dimaksud oleh peneliti, yaitu sebagai metode langkah demi langkah secara pasti dalam memecahkan suatu masalah penelitian yang mendatangkan hasil keterangan deskriptif yang benar dan nyata berupa kata-kata tertulis atau lisan dari orangorang dan perilaku yang mampu diperhatikan. ${ }^{14} \mathrm{Hal}$ ini disebabkan adanya penerapan metode kualitatif untuk mengkaji misi penginjilan dari masa penciptaan dalam teks Alkitab Kejadian 1 dan misi penginjilan pada masa kini, khususnya di Jemaat GKE Hosianna Palangka Raya yang kemudian mengalami perubahan semenjak pandemi covid-19 pada bulan Maret 2020.

Selain itu, penulis menggunakan kajian literatur sebagai salah satu sumber dalam penulisan ini. Kajian literatur ini diperoleh dari Alkitab, jurnal-jurnal, dan buku-buku yang mendukung argumen penulis dalam tulisan ini. Dalam menganalisis data-data tersebut, penulis menggunakan tindakan rasional menurut Max Weber dan teori perubahan sosial dari Talcott Parson. Penulis menemukan bahwa seiring dengan proses dan perubahan yang terjadi hingga kini, maka mempengaruhi pendekatan-pendekatan kontekstualisasi yang digunakan demi mencapai misi penginjilan, yakni untuk membawa shalom (kabar baik) kepada manusia dan seluruh ciptaan-Nya yang terdiri atas beberapa bagian yang mempunyai hubungan saling menyatu dalam keseimbangan. Pendekatanpendekatan yang dilakukan ini mengikuti perubahan-perubahan yang sesuai dengan situasi dan kondisi yang terjadi pada masa pandemi covid-19, maka diperlukan tindakan rasional yang sesuai juga dengan hal-hal yang mempengaruhinya.

\section{Hasil dan Pembahasan}

\section{Misi Penginjilan pada Masa Penciptaan pada Teks Alkitab Kejadian 1}

Hal yang mendasar dari kisah penciptaan ilmiah sebaris dengan yang dinyatakan oleh kebanyakan agama tentang cerita penciptaan, karena semua yang ada berasal dari sumber dan proses yang sama, sehingga ada suatu keadaan yang belum dapat memikul tanggung jawabnya sendiri. ${ }^{15}$ Salah satu pokok kepercayaan Israel yaitu keyakinan akan Allah sebagai pencipta. ${ }^{16}$ Allah membuat (mengadakan) sesuatu yang baru (belum pernah ada, luar biasa, lain dari yang lain) manusia dan

12 Helmuth Y. Bunu, Metodologi Penelitian, ed. Eddy Lion Muhammad Basrowi, Suwandi, Soenyono, I. (Surabaya: Jenggala Pustaka Utama, 2015).

${ }^{13}$ Lexy J. Moleong, Metodologi Penelitian Kualitatif, 39th ed. (Bandung: Remaja Rosdakarya, 2019).

14 Bunu, Metodologi Penelitian.

${ }_{15}$ Paul F. Knitter, Satu Bumi Banyak Agama: Dialog Multiagama Dan Tanggung Jawab Global, 4th ed. (Jakarta: Gunung Mulia, 2008).

${ }^{16}$ Y.M. Seto Marsunu, Allah Leluhur Kami: Tema-Tema Teologis Taurat (Yogyakarta: Kanisius, 2008). 
seluruh alam semesta dan segala yang ada di dalamnya. Berdasarkan Alkitab, Allah adalah asal dari berbagai arti atau sumber, fondasi, dan tenaga yang menggerakkan bagi penginjilan. ${ }^{17}$ Dalam pernyataan diri-Nya, penginjilan, penciptaan, dan janji berkat, serta perintah atau arahan yang diberikan untuk proses menginjili merupakan wujud pernyataan diri Allah di dalam sejarah penyelamatan-Nya atas umat manusia. Teks Alkitab dalam Kejadian 1:1-2:4a, penulis menggunakan bahasa Ibrani dengan keelokkan yang mengagumkan untuk menegaskan bahwa segala sesuatu hanya ada, karena sesuatu yang dikatakan yang mempunyai tujuan untuk memerintah supaya melakukan sesuatu dan Allah mempunyai kekuasaan membuat keputusan, memerintah, dan melimpahkan tanggung jawab kepada orang lain. ${ }^{18}$ Penulis tidak membenarkan (pendapat) dunia yang tidak melalui jalan yang benar pada zamannya. Orang memperhatikan alam dan kekuatan-kekuatannya sebagai makhluk-makhluk yang mempunyai sifat-sifat Tuhan pada zaman dahulu. Manusia dan alam tidak dipahami dengan cara berlainan. Gejala alam dianggap sebagai pengalaman manusia.

Manusia hidup di dunia yang bersifat sangat manusia sebagai perseorangan (diri manusia atau diri sendiri) dan biasanya pribadinya yang sudah diatur baikbaik dan seimbang. Akan tetapi, pribadinya kadang-kadang menjadi lain (berbeda) dari semula, goyah, dan sangat membangkitkan perasaan takut. Melalui Kejadian 1:1, salah satu pesan pokok yang mampu dibuat sebagai penerangan adanya penciptaan sudah dikerjakan Allah. ${ }^{19}$ Dia sendiri yang juga sudah mengawalinya dengan menjadikan langit dan bumi. ${ }^{20}$ Dalam pendapatnya, alam terjadi atas perintah Allah. Ia telah sedia sebelum alam ini hadir dan tidak berkait pada sesuatu yang lebih tinggi dari padanya. Matahari, bulan, binatang-binatang, dan planetplanet yang dipandang orang Babel sebagai dewa-dewa yang menyusun kejadiankejadian dalam hidup manusia, sama sekali tidak disebut. Benda-benda angkasa itu hanyalah penerang yang memancarkan cahaya kepada bumi (ay 16-18). Laut dan darat tidak lagi merupakan ibu dunia yang menjadikan hal-hal yang lain, melainkan ditempatkan pada keanikedaan sesungguhnya (ay 10). Penulis tidak menganggap alam sebagai yang disembah, karena proses, cara, perbuatan mendewakan terhadap alam menuju kepercayaan atau pemujaan kepada lebih dari satu Tuhan.

Kisah penciptaan ini juga memperkirakan keberadaan bumi yaitu teori tentang asal mula terjadinya benda langit dan alam semesta Babilonia, Atrahasis, dan Enuma Elish. ${ }^{21}$ Pemikiran Yunani ini juga menyeleweng dari ide atau pengertian yang diabstrakkan dari peristiwa konkret penganut politeisme ini. ${ }^{22}$

17 Yakob Tomatala, Penginjilan Masa Kini Jilid 2, Kedua. (Malang: Gandum Mas, n.d.).

18 W. S. LaSor, Pengantar Perjanjian Lama 1: Taurat Dan Sejarah.

${ }^{19}$ Bernike Sihombing, "Studi Penciptaan Menurut Kitab Kejadian 1 : 1-31," Jurnal Kurios: Jurnal Teologi dan Pendidikan Agama Kristen 1, no. 1 (2013): 1-31, https:/ /www.sttpb.ac.id/ejournal/index.php/kurios/article/view/15.

${ }^{20}$ Djonly J. R. Rosang, “Studi Kritik Teori Penciptaan Dalam Kejadian 1:1-2 (Suatu Kajian Terhadap Argumentasi Teori Celah)," HUPERETES: Jurnal Teologi dan Pendidikan Kristen 1, no. 1 (2019): 62-78.

${ }^{21}$ Agus Kriswanto, “Tohu Wabohu Dan Creatio Ex Nihilo: Tafsir Kejadian 1:1-2 Sebagai Perspektif Memahami Realitas Anomali," Mitra Sriwijaya: Jurnal Teologi dan Pendidikan Kristen 1, no. 1 (2020): $1-3$.

22 W. S. LaSor, Pengantar Perjanjian Lama 1: Taurat Dan Sejarah. 
Filsuf-filsuf Yunani menganggap pemikiran rasional dan bersifat spekulasi lebih unggul daripada pemikiran yang institusional dan kabur. Pemikiran rasional dan spekulatif ini, mereka menghendaki pertimbangan tentang baik buruk dan sebagainya atau proses pemikiran manusia. Sebagai ganti ilah-ilah mitologis yaitu alam yang terwujud dalam berbagai realitas dunia.

Berkaitan dengan penulis Kejadian 1, Bernike Sihombing mengatakan bahwa makna kata 'bara' yaitu tentang cipta atau karya. ${ }^{23}$ Dalam Bible work versi 6 kata bara' adalah kata kerja Perfect orang ketiga tunggal maskulin, sehingga bisa dipahami berdasarkan kata kerja yang diartikan: "dia telah menciptakan." Melihat diadakan kata bara sebagai kata kerja pada orang ketiga tunggal diketahui berasal vokal yang digunakan. Jika dirujuk pada tata bahasa Ibrani, bara bukan kata kerja Perfect, karena vokal yang digunakan pada konsonan pertama dan kedua adalah vokal panjang, maka seharusnya adalah kata benda atau kata dasar. Kata bara' ini digunakan berhubungan dengan perbuatan Allah dalam Kejadian 1:1, 21 dan 27 dengan pemahaman yang istimewa mengenai khusus tentang Allah. ${ }^{24}$ Kata bara' adalah perbuatan Allah menjadikan dengan tidak memakai media atau bahan atau materi yang suda ada. Namun suatu perbuatan yang menjadikan sesuatu yang belum ada, sehingga ada. Sebab sebelum penciptaan, tiada kenyataan eksistensi apapun.

Penulis Kejadian 1 ini mempergunakan kata Ibrani bara "menciptakan," suatu kata dalam Perjanjian Lama yang hanya digunakan bagi Allah saja tanpa menyebut sama sekali bahan yang dipakai untuk menciptakan. ${ }^{25}$ Kata ini melukiskan pekerjaan yang tidak ada perihal samanya dengan tugas kewajiban manusia dan tidak dapat dialihbahasakan dengan istilah seperti "menciptakan" atau "membangun." Dengan demikian, pasal ini melukiskan jenis pekerjaan yang hanya dapat dilakukan oleh Allah saja. Allah saja yang menciptakan, sebagaimana Allah pun yang meluputkan (menghindarkan, membebeskan) dari bahaya (bencana dan sebagainya).

Ketika melihat serta memahami isi dari apa yang tertulis dengan teliti runtunan perubahan (peristiwa) dalam perkembangan sesuatu penciptaan ini, maka akan mendapatkan sesuatu yang belum ada sebelumnya bahwa penulis kitab Kejadian beberapa kali memakai kata Allah memandang itu sebagai sesuatu yang baik untuk melukis bahwa Allah sendiri mengecap dan kagum akan karya ciptaanNya. ${ }^{26}$ Unsur yang sangat penting dalam Kejadian ialah adanya penjelasan bahwa dunia ciptaan Allah itu elok (ay 4, 10, 12, 18, 21, 25, 31). Ikhtisar akhir (ayat 31), "Maka Allah melihat segala sesuatu yang dijadikanNya itu sungguh amat baik" menunjukkan dengan jelas bahwa bahasa pasal itu ringkas, lazim, dan tidak sangat lebih dari keadaan sebenarnya. Allah tidak menempatkan perbuatan yang jahat apapun di dunia ciptaanNya. Dunia mempunyai nilai yang mulia, tetapi hanya

${ }^{23}$ Sihombing, "Studi Penciptaan Menurut Kitab Kejadian $1: 1-31 . "$

${ }^{24}$ Rosang, "Studi Kritik Teori Penciptaan Dalam Kejadian 1:1-2 (Suatu Kajian Terhadap Argumentasi Teori Celah)."

${ }^{25}$ W. S. LaSor, Pengantar Perjanjian Lama 1: Taurat Dan Sejarah.

${ }^{26}$ Kosma Manurung, "Taurat Dan Nubuat Palsu: Kajian Sudut Pandang Taurat Terhadap Nubuat Palsu," Jurnal Teologi Berita Hidup 2, no. 2 (2020), https:/ / www.ejournal.sttberitahidup.ac.id/index.php/jbh/article/view/31. 
karena Allahlah yang menjadikannya. Petunjuk tentang kegunaan ciptaan yang suci penting sekali secara teologis, termasuk manusia. ${ }^{27}$ Pertama, petunjuk itu menyediakan jawaban untuk pertanyaan tentang apa yang merintangi keteraturan yang baik ini yaitu dosa. Kedua, ajaran itu mengatur segala sesuatu (untuk) penjelasan Alkitab jauh pada zaman kemudian, yaitu pada waktu Allah akan melihat bahwa semua yang telah diciptakanNya sangat teratur adanya, karena akan ada "langit baru dan bumi baru" (Wahyu 21:1).

Kemudian pad teks Kejadian 1:27 yang mengacu kepada manusia pertama yang diciptakan oleh Allah. ${ }^{28}$ Pria dan wanita diciptakan serupa dan segambar dengan Allah. Hal tersebut diketahui bahwa antara pria dan wanita tidak ada ada pembedaan sikap dan perlakuan terhadap sesama manusia di hadapan Allah antara pria dan wanita itu sejajar bagi-Nya. Akhirnya, puncak paling tinggi dari penciptaan ini adalah manusia (Kej. 1:26-28). ${ }^{29}$ Melalui pemberitahuan tersebut nampak bahwa Allah membuat dunia dan isinya memperlihatkan bahwa misi Allah dalam penciptaan tersebut merupakan misi yang umum (berlaku untuk semua orang atau untuk seluruh dunia) terhadap ciptaanNya dan Allah sendiri mempertalikan dirinya dengan dunia secara universal. Selain itu, Allah menyerahkan perintah budaya kepada manusia yaitu untuk menjadi banyak dan menundukkan dunia (Kej. 1:26). Hal ini menunjukkan bahwa Allah dari awalnya berhubungan dengan manusia dalam arti umum (berlaku untuk semua orang atau untuk seluruh dunia) yaitu manusia (dari segala bangsa dan bukan istimewa misalnya, Israel saja). Manusia ditinggikan dan diperlakukan sebagai pemegang kekuasaan, imitasi, dan citra Allah yang hidup. ${ }^{30}$

Pemberian dan pengangkatan tugas ini sangat membedakan manusia dari segala makhluk hidup yang lain. Dinyatakan bahwa Allah menjadikan manusia segambar dan serupa dengan Allah, dan manusia merupakan yang diciptakan-Nya yang paling tinggi. ${ }^{31}$ Kosma Manurung mengatakan bahwa makna dijadikan menurut citra Allah berkaitan aturan terpenting dari pihak atas yang harus dilakukan yaitu mencintai Tuhan dan mencintai sesama. ${ }^{32}$ Bagian tersebut menjadi keterlibatan yang berlanjut dan penerapan dari masalah manusia dijadikan menurut citra dan rupa Allah. Manusia sama halnya dengan seorang gubernur tidak lebih dari berkuasa atas daerah yang dikuasainya, semasa dia bertalian pada sesuatu yang lebih tinggi kepada pemerintah agung. ${ }^{33}$ Demikianlah juga manusia hanya berkuasa atas dunia, selama dia taat dan menyandarkan diri kepada Allah.

27 W. S. LaSor, Pengantar Perjanjian Lama 1: Taurat Dan Sejarah.

${ }^{28}$ Sihombing, "Studi Penciptaan Menurut Kitab Kejadian $1: 1-31 . "$

29 W. S. LaSor, Pengantar Perjanjian Lama 1: Taurat Dan Sejarah.

${ }^{30}$ Walter Lempp, Tafsiran Alkitab Kejadian (1:1-4:26), keempat. (Jakarta: Gunung Mulia, 1987).

${ }^{31}$ Yusup Rogo Yuono, "Etika Lingkungan : Melawan Etika Lingkungan Antroposentris

Melalui Interpretasi Teologi Penciptaan Yang Tepat Sebagai Landasan Bagi Pengelolaan-Pelestarian Lingkungan," FIDEI: Jurnal Teologi Sistematika dan Praktika 2, no. 1 (2019): 183-203. Palsu."

32 Manurung, "Taurat Dan Nubuat Palsu: Kajian Sudut Pandang Taurat Terhadap Nubuat

33 Yuono, "Etika Lingkungan : Melawan Etika Lingkungan Antroposentris Melalui Interpretasi Teologi Penciptaan Yang Tepat Sebagai Landasan Bagi Pengelolaan-Pelestarian Lingkungan." 
Dia tidak lain dari menjadi tuan besar semasa dia ber-Tuhan. ${ }^{34}$ Wewenang yang melekat dalam diri manusia ini, dikarenakan kekhususan manusia yang dijadikan menurut citra dan tokoh yang menciptakan-Nya. ${ }^{35}$ Gagasan mengenai citra ini menunjukkan kemampuan gagasan dari bagian Timur Dekat Kuno tentang patung atau gambar seorang raja mampu difungsikan untuk menerangkan atau menentukan daerah kekuasaannya. Terkait dengan kesegambaran manusia dengan Allah (imago Dei) bukanlah suatu tanda lahiriah, situasi yang sedang berlaku atau watak yang berada dalam kesadaran atau dalam akal budi (pikiran) pada manusia, melainkan kedudukannya diterimanya, karena bertemu muka dengan Allah dan karena pertaliannya dengan Allah. ${ }^{36}$

Menurut Alkitab, Allah adalah asal fondasi dan kekuatan yang menggerakkan bagi penginjilan. ${ }^{37}$ Adapun bentuk pernyataan dari Allah dalam sejarah pembebasan dari bahaya (bencana dan sebagainya) penyelamatan bagi manusia yaitu penginjilan penciptaan, dan ketentuan (yang harus dipenuhi) yang mendatangkan kebaikan, serta mandat penginjilan. Penginjilan dan penciptaan Allah merupakan kemampuan atau kesanggupan (untuk berbuat sesuatu) bagi penginjilan (Kejadian 1:1) yang menjelaskan bahwa Allah yang menandakan diri sebagai pencipta. Sebagai yang menciptakan, Allah adalah mempunyai kekuasaan tertinggi atas ciptaannya. Melalui kekuasaan tertingginya, Ia telah menjadikan sesuatu dan menopang penciptaan-Nya dengan "janji berkat-Nya" (Kejadian 1:28; 2:3).

Menurut Y. Y. Tomatala, konsep kegiatan menyebarkan Kabar Gembira (Injil) dan mendirikan jemaat setempat, dilakukan atas dasar pengutusan sebagai kelanjutan misi Kristus (penyelamatan Allah) telah Ia dinyatakan cepat, setelah manusia masuk ke dalam dosa (Kejadian 3:15) mempunyai maksud bahwa janji keselamatan yang digemakan pada saat itu telah dapat dibuktikan secara hukum mempunyai kesalahan dan tidak berkekuatan. ${ }^{38}$ Janji keselamatan itu bersifat mengenai hal-hal terakhir yaitu melihat ke depan, ke waktu yang diizinkan Allah (Galatia 4:4) dan bersifat Messianik juga, karena akan ditepati oleh seorang penyelamat yaitu Kristus/Mesias sebagai mediator (Matius1:18-25; Lukas 1:31-35; II Timotius 2:5; Yesaya 6:14 dan sebagainya). Selain itu, kisah penciptaan ini juga bermula dari lingkungan para imam yang diarahkan untuk paguyuban kaum buangan pada abad VI SM dan untuk tidak membenarkan (pendapat) pernyataan tentang suatu fakta atau kebenaran teologi Babel. Pengalaman Israel di tanah pembuangan Babel dan pertemuan mereka dengan kebudayaan Babel menganjurkan mereka untuk menatap ke keadaan semula akan iman kepada YHWH, Allah Israel. ${ }^{39}$ Palsu."

${ }^{34}$ Lempp, Tafsiran Alkitab Kejadian (1:1-4:26).

${ }^{35}$ Manurung, "Taurat Dan Nubuat Palsu: Kajian Sudut Pandang Taurat Terhadap Nubuat

${ }^{36}$ Lempp, Tafsiran Alkitab Kejadian (1:1-4:26).

${ }^{37}$ Jesly Nurlatu, "Kurangnya Penginjilan Pada Pertumbuhan Gereja Masa Kini," Jurnal Strategi Pertumbuhan Gereja (2020).

38 Yakob Tomatala, Penginjilan Masa Kini Jilid 2.

${ }^{39}$ Marsunu, Allah Leluhur Kami: Tema-Tema Teologis Taurat. 


\section{GKE Hosiana Palangka Raya}

Gereja Dayak Evangelis (GDE) dirintis oleh Zending Barmen dan Zending Basel melaksanakan pekerjaan yang menjadi tanggung jawabnya dan misi Kristiani di Pulau Kalimantan. ${ }^{40}$ Kemudian keabsahan perubahan nama "EVANGELISCHE DAJAKSCHE KERK" menjadi “GEREJA KALIMANTAN EVANGELIS" terjadi pada tanggal 24 April 1937 yang didasarkan pada Surat Keputusan Gubernur Jenderal Hindia Belanda No. 23 (Staatsblad No. 217). GKE (Gereja Kalimantan Evangelis) yaitu suatu lembaga yang disusun baik-baik oleh peraturan yang secara resmi dianggap mengikat. GKE merupakan gereja yang sedang berkembang di Pulau Kalimantan yang luasnya sekitar $553.000 \mathrm{KM}$ dengan suku Dayak sebagai penduduk mayoritas. ${ }^{41}$ Dalam lintasan ruang dan waktu, GKE merajut cita-cita dengan usaha yang penuh dengan kesukaran dan bahaya menuju kepada hal atau keadaan dapat berdiri sendiri tanpa bergantung pada orang lain. Kemandirian ini dapat dikerjakan tentu melalui berbagai langkah strategi yang telah ditetapkan untuk meraih kemandirian tersebut. Dari hal tersebut, kemudian hadirlah salah satu GKE Hosianna di Jalan Iskandar No. 02 Palangka Raya, resort Palangka Raya Hilir. Jemaat GKE Gereja Hosianna di Palangka Raya yang berkedudukan di kota Palangka Raya, Kelurahan: Langkai, Kecamatan: Pahandut, Provinsi: Kalimantan Tengah.

GKE Hosianna menyelenggarakan ibadah Minggu. Ibadah Minggu dihadiri oleh warga jemaat yang majemuk mulai dari keberagaman usia, selera musik, dan pendidikan. GKE Hosianna ini terdiri dari orang suku Dayak Ngaju (90\%) dan 10\% di luar suku Dayak Ngaju (misalnya suku Dayak Ma'anyan, suku Batak, dan suku Jawa). ${ }^{42}$ Seiring dengan proses dan perkembangan GKE Hosianna, kemudian bentuk persekutuan itu didramatisasikan secara dialogis dalam bentuk tata cara kebaktian. Bentuk liturgi ada empat (4) bentuk liturgi dalam ibadah Minggu pada setiap minggunya. ${ }^{43}$ Ibadah hari Minggu pertama menggunakan dua bentuk liturgi dengan waktu yang berbeda. Pertama, bentuk liturgi I yang digunakan pada pukul 05.30 WIB adalah menggunakan Bahasa Indonesia. Kedua, bentuk liturgi yang digunakan pada pukul 08.00 WIB adalah menggunakan kutak (bahasa) Dayak Ngaju. ${ }^{44}$ Dilihat dari segi pemakaiannya dalam liturgi ini, nyanyian rohani berbahasa Dayak Ngaju ini digunakan lebih dominan daripada nyanyian rohani berbahasa Indonesia. Minggu ke dua sampai ke lima menggunakan bahasa Indonesia.

Dalam liturgi-liturgi tersebut, nyanyian rohani memiliki peranan penting dalam ibadah Minggu. Sebab nyanyian rohani merupakan salah satu ungkapan pujian kepada Tuhan Yang Maha Kuasa. Hal ini dapat dilihat dalam kitab Keluaran 15 ayat 1-18 yang menuliskan nyanyian Musa dan bangsa Israel. Mereka bersyukur, karena Tuhan selalu menunjuk (mengarahkan) bangsa Israel ke jalan

${ }^{40}$ Mahin, 70 Tahun GKE: Pergumulan Dan Upaya GKE Menuju Kemandirian.

${ }^{41}$ Telhalia Telhalia, “Teologi Kontekstual Pelaksanaan Jalan Hadat Perkawinan Dayak Ngaju

Di Gereja Kalimantan Evangelis (GKE)," Religió: Jurnal Studi Agama-agama 6, no. 2 (2016): 230-252.

42 Hasil wawancara dengan Marni Simpun pada tanggal 29 Juli 2021.

${ }^{43}$ Berdasarkan Warta Jemaat GKE Hosianna Minggu, 01 Mei 2016.

${ }^{44}$ Bahasa Dayak Ngaju merupakan bahasa lokal yang dipergunakan oleh masyarakat asli suku Dayak Ngaju. 
yang benar. Dalam hal ini, Allah dimuliakan karena mujizat-Nya yang dilihat dan dirasakan oleh orang Israel. ${ }^{45}$ Nyanyian rohani ini mempunyai dimensi dan fungsi antara umat dan Tuhan sebagai Sang Pencipta dan antarumat itu sendiri. Selain itu, salah satu teks Alkitab lainnya dalam Mazmur 23:1-7. Teks tersebut menunjukkan bahwa pemazmur dengan jelas mengatakan bahwa 'Tuhan adalah gembalaku'. Allah menjadikan sama diriNya dengan seorang gembala untuk menggambarkan kasihNya yang besar bagi umatNya. ${ }^{4647}$ Dari pemaknaan ini, nyanyian rohani tersebut berfungsi sebagai relasi manusia dengan Tuhan. Dari sisi lain, penggunaan musikalitas yang baik akan memberikan benturan yang baik pada jemaat. ${ }^{48}$

Selanjutnya, GKE Hosianna menggunakan buku Nyanyin Ungkup dalam liturginya. Nyanyin Ungkup merupakan nyanyian dengan syair bahasa Dayak Ngaju yang diterbitkan oleh Yayasan Musik Gerejawi Gereja Kalimantan Evangelis (YAMUGER GKE) ${ }^{49}$ ke dalam notasi angka empat suara (SATB). Dengan not angka 4 (empat) suara yang bisa membantu warga jemaat untuk menyanyikan Nyanyin Ungkup dalam bentuk paduan suara. Berdasarkan tulisan Nyanyin Ungkup Empat Suara (SATB) dari Yayasan Musik Gerejawi Gereja Kalimantan Evangelis (YAMUGER GKE) mengatakan bahwa Nyanyin Ungkup ini memang sudah ada sejak lama, bahkan hampir sama usianya dengan awal misi Pekabaran Injil di Kalimantan. Sebagaimana yang telah dikatakan oleh Melkiannus Paul Lambut bahwa sebagai penganut agama Kristen, orang Dayak wajib bergelut dengan kedayakkannya. ${ }^{50}$

Sebenarnya Alkitab sudah diterjemahkan dengan baik ke dalam bahasa Dayak Ngaju, disertai Buku Nyanyin Ungkup dalam bahasa Ngaju dan ditambahkan sesuatu yang kurang supaya menjadi lengkap dengan buku Batang Ajar yang mencoba menerjemahkan buku Katekismus Heidelberg. Nyanyin Ungkup tersebut terdapat di dalam Buku "Soerat Lagon Njanji" yang ditulis dalam notasi balok yang diterbitkan oleh F.W. Gadow dan Sohn G.m.Hm di Hildburghausen. BPH Majelis Sinode Gereja Kalimantan Evangelis yang telah menyetujui penerbitan Buku Nyanyian ini dengan surat Persetujuan nomor:188/BPH-MSGKE/U.11/03/2004 tanggal 16 Maret 2004. ${ }^{51}$ Dengan adanya 364 nomor lagu Nyanyin Ungkup tersebut terdapat 54 nomor lagu yang belum ditulis ke dalam empat suara, sehingga YAMUGER GKE merasa membutuhkan sebuah team untuk membuat dan

45 Enggar Objantoro, "Sejarah Dan Pemikiran Kaum Injili Di Tengah-Tengah Perubahan Dan Tantangan Zaman," Evangelikal: Jurnal Teologi Injili dan Pembinaan Warga Jemaat 1, no. 2 (2017): 129.

${ }^{46}$ Bherton Ferdinan, "Peranan Gembala Dan Strategi Penggembalaan Dalam Meningkatkan Pembinaan Jemaat," STELLA: Jurnal Teologi dan Pendidikan Kristen 1, no. 1 (2021): 45-56.

${ }^{48}$ Markus Wibowo, "Peranan Musik Gereja Dalam Pembentukan Karakter Jemaat Dan Pembawa Misi Gereja Di Gereja Bethany Indonesia Menara Doa Melonguane," PSALMOZ A Journal of Creative and Study of Church Music 1 (2020): 1-14, http:/ / ejournal-iakn-

manado.ac.id/index.php/psalmoz/article/view/192/192.

${ }^{49}$ Yayasan Musik Gerejawi Gereja Kalimantan Evangelis (YAMUGER GKE), Nyanyin Ungkup Empat Suara (SATB), iii. (Palangka Raya: YAMUGER GKE, 2006).

${ }^{50}$ Melkiannus Paul Lambut, “Narasi Kesejarahan Perjuangan Tanpa Henti Gereja Kalimantan Evangelis Sejak Cikalbakal 1835 Hingga Kini," Jurnal Pambelum: Teologi Kontekstual 5, no. 2 (2015), https://stt-gke.ac.id/wp-content/uploads/2020/08/Volume-5-Nomor-2-Desember-2015.pdf.

${ }^{51}$ GKE, Nyanyin Ungkup Empat Suara (SATB). 
mentransfer lagu tersebut dari Buku “Soerat Lagon Njanji” ke dalam notasi angka. Akan tetapi, nyanyian rohani berbahasa Dayak Ngaju mulai terpinggirkan atau tergeser, karena nyanyian rohani berbahasa Indonesia. Pertama, terbitnya buku nyanyian rohani buku kedua yang telah terbit tahun 1975, tetapi digunakan sejak tahun 2000-an di GKE yaitu buku Nyanyian Kidung Baru (NKB) dan Pelengkap Kidung Baru (PKB). Buku-buku nyanyian rohani tersebut dengan cepat diterima dan digunakan oleh gereja-gereja yang ada di Indonesia termasuk juga jemaat GKE Hosianna di Palangka Raya.

Selain itu, meluasnya globalisasi yang menyebabkan terjadinya perubahan dalam kehidupan manusia. Pengaruh globalisasi menjadi tantangan tersendiri. ${ }^{52}$ Misalnya, adanya anggapan bahwa bahasa asing lebih sesuai dengan tuntutan zaman dan bergengsi sosial yang lebih tinggi. ${ }^{53}$ Hal lain yang menyebabkan terpinggirnya nyanyian rohani berbahasa Dayak Ngaju ini juga, karena adanya bahasa alay sebagai bahasa gaul pada masa ini yang mempunyai hubungan erat dengan masyarakat penggunanya. ${ }^{54}$ Hubungan keduanya tidak sekedar sebatas pada bahasa sebagai alat komunikasi, tetapi juga merupakan refleksi dari pikiran, sikap, dan sebuah budaya. Dalam konteks pandemi covid-19, penggunaan nyanyian rohani berbahasa Dayak Ngaju belum dapat digunakan oleh GKE Hosianna. ${ }^{55}$ Situasi yang terjadi saat ini jelas menimbulkan kekhawatiran masyarakat. ${ }^{56}$ Dari beberapa penyebab tersebut, maka GKE Hosianna melakukan beberapa strategi-strategi dalam tindakan rasional untuk mengikuti perubahanperubahan yang selaras dengan situasi dan kondisi yang terjadi.

\section{Implikasi}

Melalui pemikiran Max Wber tentang tindakan rasional dan Talcott Parsons mengenai teori perubahan, maka yang menjadi persoalan dalam tulisan ini yaitu Apa dampak positif dan negatif pada misi penginjilan dari masa penciptaan dan pada masa pandemi covid-19? Rasionalitas digunakan sebagai alat untuk mencari dan menemukan, serta mengerti aktor yaitu baik individu maupun kelompok dalam melakukan tindakan sosial berdasarkan motif dan tujuan yang diharapkan aktor atas tindakan sosial yang sudah dilaksanakannya. ${ }^{57}$ Artinya, tindakan sosial itu memiliki arti subjektif dari pelaku tindakan dan terarah kepada orang lain. ${ }^{58}$

52 Hasil wawancara dengan Marni Simpun pada tanggal 29 Juli 2021.

${ }^{53}$ Marsudi Marsudi and Siti Zahrok, "Kesetiaan Berbahasa Indonesia Dipertanyakan Di Era Globalisasi," Jurnal Sosial Humaniora 8, no. 1 (2015): 95.

54 Fahmi Gunawan et al., "Bahasa Alay: Refleksi Sebuah Budaya," Jurnal Bahasa dan Sastra 10, no. 2 (2011), http://202.0.92.5/adab/Adabiyyat/article/view/735.

${ }^{55}$ Hasil wawancara dengan Marni Simpun pada tanggal 29 Juli 2021.

56 Aprista Ristyawati, "Efektifitas Kebijakan Pembatasan Sosial Berskala Besar Dalam Masa Pandemi Corona Virus 2019 Oleh Pemerintah Sesuai Amanat UUD NRI Tahun 1945," Administrative Law and Governance Journal 3, no. 2 (2020): 240-249.

${ }^{57}$ Agus Mahfud Fauzi Prastu Heri Wibowo, "Rasionalitas Masyarakat Memilih Calon Bupati Milenial Di Kalangan Sesepuh Desa Sumberbening Kecamatan Dongko Kabupaten Trenggalek," Jurnal Ilmu Politik dan Pemerintahan 7, no. 1 (2021), http://jurnal.unsil.ac.id/index.php/jipp/article/view/2938.

${ }^{58}$ Nerrisa Erviana Hadianti Kustoyo and Siti Zunariyah, "Pemaknaan Mahasiswa Terhadap Simbol Pancasila Sebagai Identitas Bangsa," Journal of Development and Social Change 2, no. 2 (2020): 3. 
Salah satu tindakan rasionalnya yaitu tindakan yang berdasarkan pertimbangan dan pilihan yang sadar yang berhubungan dengan tujuan tindakan itu dan alat yang dipergunakan untuk mencapainya (rasionalitas instrumental). ${ }^{59}$

Sejalan dengan itu, Robert B. Coote menjelaskan bahwa para penulis bekerja kepada para penguasa yang tidak pelajar (Palestina purba) seperti para imam, dan orang-orang terpelajar. ${ }^{60}$ Dengan mengingat dan memahami bahwa literatur pada masa dahulu (dunia purba) merupakan suatu hasil karya bidang sastra yang sangat langka, sulit, tidak tersebar secara luas, dan terbatas dari satu komunitas sosial yang eksklusif, walaupun setelah penemuan huruf alfabet (3700 tahun lalu) dengan sistem tulisan lebih kurang $25 .{ }^{61}$ Meminjam bahasa yang digunakan Ritzer mungkin tindakan ekonomi dalam sistem pasar yang bersifat impersonal yang tercermin dalam organisasi birokratis ${ }^{62}$ yang mempengaruhi kelompok penulis tersebut mempunyai keterampilan tulis menulis yang kemudian mempunyai pengaruh sangat menentukan bagi karya-karya literatur atau sastra. ${ }^{63}$

Singkatnya, Alkitab berisi himpunan dari bermacam hasil sastra manusia, dan untaian peristiwa yang berpengaruh pada kehidupan politik, sosial, budaya dan ekonomi pada saat itu. Dengan kata lain, Alkitab terbangun selaras dengan pandangannya bersumber pada dunia dan Alkitab bukanlah pewahyuan langsung dari Allah kepada agama/aliran keyakinan tertentu. Hal yang nampak dari misi penginjilan dari masa penciptaan dan masa pandemi covid-19 dilihat dari sudut pandang skema AGIL (Adaptation, Goal Attainment, Integration, and Latency) Talcott Parsons dengan konsep utamanya yaitu ada fungsi, disfungsi, fungsi laten, fungsi manifest dan keseimbangan (equilibrium). ${ }^{64}$

Pertama, adaptasi (adaptation) merupakan sebuah sistem yang mesti mengatasi keadaan eksternal yang berbahaya. Sistem harus menjadikan sesuai dengan lingkungan dan menyamakan lingkungan itu dengan kebutuhannya. Dalam hal ini, penulis teks Alkitab dalam Kejadian 1:1-2:4a menggunakan bahasa Ibrani dengan keelokkan yang mengagumkan untuk menegaskan bahwa segala sesuatu hanya ada, karena sesuatu yang dikatakan yang mempunyai tujuan untuk memerintah supaya melakukan sesuatu dan Allah mempunyai kekuasaan membuat keputusan, memerintah, dan melimpahkan tanggung jawab kepada orang lain. Unsur yang sangat penting dalam Kejadian ialah adanya penjelasan bahwa dunia ciptaan Allah itu elok dengan puncak paling tinggi dari penciptaan ini adalah manusia. Allah dari awalnya berhubungan dengan manusia dalam arti umum

59 Doyle Paul Johnson, Sociological Theory Classical and Contemporary Perspectives (Jakarta: Gramedia, 1986).

${ }^{60}$ Robert B. Coote \& David Robert Ord, In the Beginning: Creation and the Priestly History, (Mineapolis: Fortress Press, 1991).

61 Robert B. Coote \& David Robert Ord, The Bible's First History: From Eden to the Court of David with the Yahwist (Philadelphia: Fortress Press, 1989).

62 Teguh Prakoso, "Rasionalitas Like Di Sosial Media Siswa Sma Negeri 1 Teras, Boyolali," Sosialitas: Jurnal Ilmiah Pend. Sos Ant 5, no. 2 (2015), https://jurnal.fkip.uns.ac.id/index.php/sosant/article/view/10376.

63 Ord, The Bible's First History: From Eden to the Court of David with the Yahwist.

64 Andina Prasetya, Muhammad Fadhil Nurdin, and Wahju Gunawan, "Perubahan Sosial Masyarakat Dalam Perspektif Sosiologi Talcott Parsons Di Era New Normal," Sosietas Jurnal Pendidikan Sosiologi 11, no. 1 (2021): 929-939. 
(berlaku untuk semua orang atau untuk seluruh dunia) yaitu manusia (dari segala bangsa dan bukan istimewa misalnya, Israel saja).

Berdasarkan perubahan perilaku, jemaat GKE Hosianna yang dituntut untuk menyesuaikan diri sesuai dengan indikator yang ada dalam kebudayaan yang bersifat dinamis, yakni adanya kebutuhan dan motivasi jemaat menggunakan bahasa Dayak Ngaju dalam bentuk liturgi dan nyanyin ungkup. Penggunaan nyanyian rohani diciptakan sesuai dengan perkembangan dan kebutuhan jemaat pada bagian bahasa. Hal ini menunjukkan kesegambaran manusia dengan Allah (imago Dei) yang berada dalam kesadaran atau dalam akal budi (pikiran) pada manusia. Salah satu bentuk ciptaannya yaitu penggunaan bahasa Dayak Ngaju yang digunakan dalam buku Nyanyin Ungkup yang digunakan oleh jemaat GKE Hosianna di Palangka Raya. Hal ini menunjukkan adanya tindakan rasional instrumental jemaat GKE Hosianna yang kebutuhan dan motivasi jemaat menggunakan bahasa Dayak Ngaju dalam bentuk liturgi dan nyanyin ungkup.

Dalam situasi pandemi covid-19, jemaat GKE Hosianna menerima dampak negatif maupun dampak positif. Dampak negatifnya yaitu jemaat ini memang pada awalnya telah mempertahankan penggunaan Nyanyin Ungkup dalam ibadah hari Minggu liturgi bentuk ke II di GKE Hosianna Palangka Raya sebelum pandemi covid-19, sehingga GKE Hosianna tetap mempertahankan identitas kedayakannya. ${ }^{65}$ Akan tetapi, Nyanyin Dayak Ngaju terpinggirkan juga, karena hadirnya nyanyian rohani berbahasa Indonesia sejak tahun 2000-an di GKE yaitu buku Nyanyian Kidung Baru (NKB) dan Pelengkap Kidung Baru (PKB) dan adanya pengaruh globalisasi. Misalnya, adanya penggunaan bahasa alay. ${ }^{66}$ Kemudian gereja GKE Hosianna untuk sementara waktu belum dapat menyelenggarakan kebaktian hari Minggu liturgi bentuk ke II di jemaat GKE Hosianna Palangka Raya dengan menggunakan liturgi bahasa Dayak Ngaju. Dengan kata lain, ruang dan waktu jemaat GKE Hosianna Palangka Raya menjadi terbatas dalam penggunaan liturgi bahasa Dayak Ngaju baik dalam persiapan pelaksanaan maupun dari umat Tuhan yang melaksanakan pelayanannya. Sebagaimana yang diungkapkan oleh Mustaqim Pabbajah, Nurhidayat Muhammad Said, Faisal, M.Taufiq Hidayat Pabbajah, Hasse Jubba, and Juhansar bahwa perluasan covid-19 sudah mengatur kembali aturan sosial umat manusia, terhitung kehidupan individu yang melalui kehidupan beragama. ${ }^{67} \mathrm{Hal}$ ini pula yang mengubah pelaksanaan kepada penggunaan liturgi kebaktian Hari Minggu dalam bahasa Indonesia secara online atau virtual, sehingga penyelenggaraan kebaktian hari Minggu liturgi bentuk ke II di jemaat GKE Hosianna Palangka Raya dengan menggunakan liturgi bahasa Dayak Ngaju semakin terpinggirkan.

Adapun dampak positif dari misi penginjilan selama pandemi ini yaitu nampak pada keikutsertaan jemaat GKE Hosianna untuk mengurangi peningkatan penyebaran covid-19. Hal ini kelihatan dari adanya Latency yang merupakan suatu

65 Hasil wawancara dengan Marni Simpun pada tanggal 29 Juli 2021.

${ }^{66}$ Gunawan et al., "Bahasa Alay: Refleksi Sebuah Budaya."

${ }^{67}$ Mustaqim Pabbajah et al., "Deauthorization of the Religious Leader Role in Countering Covid- 19: Perceptions and Responses of Muslim Societies on the Ulama's Policies in Indonesia," International Journal of Criminology and Sociology 9, no. November (2020): 262-273. 
tahapan bahwa GKE Hosianna patut memegang teguh nilai dasar dan norma yang telah dianut bersama yaitu mematuhi aturan protokol kesehatan (prokes) yang telah dibuat oleh pemerintah. Kepatuhan akan aturan prokes tersebut menunjukkan tindakan rasional instrumental secara mendalam berdasarkan harapan atas kepentingan atau tujuan dalam tindakan yang dilakukan sesuai konteks pandemi covid-19. ${ }^{68}$ Tindakan ini juga ditentukan oleh harapan terhadap perilaku obyek atau orang lain. Harapan yang dimiliki oleh aktor inilah yang akan menentukan syarat dan sarana dalam mencapai tujuan dengan menggunakan perhitungan dan pertimbangan yang rasional. Bagian ini tentu saja tidak terlepas dari konsep yang dikenal dengan "verstehen." Dengan kata lain, konsep yang berarti "pemahaman mendalam" dalam memahami situasi yang terjadi pada masa pandemi covid-19, sehingga memerlukan perubahan-perubahan sosial yang terjadi di dalamnya. ${ }^{69}$

Salah satu tokoh yang mendalam membicarakan tentang teori perubahan adalah Talcott Parson. Menurut Parsons dalam tulisannya, Prasetya, Nurdin, dan Gunawan bahwa kerangka berpikir pada teori perubahan sosial membahas bagaimana masyarakat itu menjadi lain (berbeda) dari semula dan proses yang terjadi pada perubahan tersebut. ${ }^{70}$ Pendapat Bakhri dan Fibrianto bahwa Parsons memandang suatu persamaan diantara masyarakat dan lingkungannya yang merupakan suatu sistem yang terbuka dalam teori sistem umumnya. ${ }^{71}$ Bagian ini juga menegaskan pada keteraturan (order) dan tidak mengindahkan pertentangan dan perubahan di dalam masyarakat. Masyarakat merupakan sistem sosial yang terdiri atas beberapa bagian atau elemen-elemen yang mempunyai hubungan saling menyatu dalam keseimbangan. Dengan demikian, penulis menemukan bahwa seiring dengan proses dan perubahan yang terjadi hingga kini, maka dampak positif yang mempengaruhi tindakan-tindakan rasional yang digunakan demi mencapai misi penginjilan yaitu bertujuan untuk membawa shalom (kabar baik) kepada manusia dan seluruh ciptaan-Nya yang terdiri atas beberapa bagian yang mempunyai hubungan saling menyatu dalam keseimbangan Kedua hal tersebut saling berhubungan dan berpengaruh pada individu ataupun kelompok yang merupakan bagian dari masyarakat. Setiap kehidupan masyarakat memiliki aturanaturan dan nilai-nilai sosial yang membimbing dan mengurus perilaku. Menurut parsons yang terpenting bukanlah tindakan individual, melainkan ketentuanketentuan dan nilai-nilai tersebut. Prasetya, Nurdin, dan Gunawan mengatakan apabila tidak ada, maka sistem sosial tersebut tidak akan dapat tetap pada

${ }^{68}$ Nurhadi Edo Johan Pratama, Siti Rochani, “Solo Belajar Community Learning Tutoring For Sumber Tapen Residents Learn (Phenomenological Study In Rt 02 Rw 03 Sumber Tapen, Banjarsari, Surakarta)," SOSIALITAS; Jurnal Ilmiah Pend. Sos Ant 8, no. 1 (2017), https://jurnal.fkip.uns.ac.id/index.php/sosant/article/view/12031.

${ }^{69}$ Widjajanti Mulyona Sontoso, Ilmu Sosial Di Indonesia: Perkembangan Dan Tantangan, ed. Santoso (Jakarta: Yayasan Pustaka Obor Indonesia, 2016).

70 Prasetya, Nurdin, and Gunawan, "Perubahan Sosial Masyarakat Dalam Perspektif Sosiologi

Talcott Parsons Di Era New Normal."

${ }^{71}$ Syamsul Bakhri and Alan Sigit Fibrianto, "Hubungan Kegiatan Ekstrakurikuler Pramuka Dengan Tingkat Religiusitas Siswa Sma Negeri 1 Tangen (Perspektif Teori Sistem Sosial Talcott Parsons)," Jurnal Sosiologi Agama 12, no. 1 (2018): 67. 
tempatnya dan harus selesai. ${ }^{72}$

Hal yang nampak juga pada perubahan perilaku, jemaat GKE Hosianna yang dituntut untuk menyesuaikan diri sesuai dengan indikator yang ada dalam kebudayaan yang bersifat dinamis, yakni adanya kebutuhan dan motivasi jemaat menggunakan bahasa Dayak Ngaju dalam bentuk liturgi dan nyanyin ungkup. Penggunaan nyanyian rohani diciptakan sesuai dengan perkembangan dan kebutuhan jemaat pada bagian bahasa. Hal ini menunjukkan kesegambaran manusia dengan Allah (imago Dei) yang berada dalam kesadaran atau dalam akal budi (pikiran) pada manusia. Salah satu bentuk ciptaannya yaitu bagaiamana langkah yang tepat penggunaan bahasa Dayak Ngaju yang digunakan dalam buku Nyanyin Ungkup yang digunakan oleh jemaat GKE Hosianna di Palangka Raya. Dengan demikian, jemaat GKE Hosianna ini lahir dan berkembang menyerap unsur-unsur budaya Dayak dalam mengungkapkan imannya.

Hal ini mengingatkan tentang pengungkapan pempribumian yang paling termashyur adalah "tiga-swa," yaitu mencukupi kebutuhan sendiri (swamsebada), memerintah diri sendiri (swakelola), dan mengandalkan kemampuan sendiri (swadaya)- yang diciptakan oleh Henry Venn dan Rofus Anderson serta dikembangkan oleh Roland Allen. ${ }^{73}$ Pempribumian dimaksudkan untuk menciptakan secepat mungkin suatu gereja setempat yang tidak selamanya bergantung pada pemeliharaan dan bantuan luar negeri. Selain itu, situasi pandemi global ini membuat gereja GKE Hosianna untuk sementara waktu belum dapat menyelenggarakan hari Minggu liturgi bentuk ke II di jemaat GKE Hosianna Palangka Raya dengan menggunakan liturgi bahasa Dayak Ngaju. Akan tetapi, sisi positif dari pelaksanaan misi penginjilan pada masa pandemi covid-19 yaitu peran keluarga sebagai jawaban untuk mengisi hingga penuh atau hampir penuh kebutuhan dasar sebagai makhluk sosial. ${ }^{74}$ Keselarasan keluarga menjadi satu dari beberapa langkah agar menurunkan salah satu cara untuk mengurangi stress dan selalu dalam kawasan kesenangan dan ketenteraman hidup (lahir batin). Selain itu, anjuran untuk tinggal di rumah selama masa pandemi pasti saja menyebabkan peluang besar dan lebih lama berinteraksi bersama keluarga dibandingkan dengan masa sebelum pandemi covid-19.75

Kedua, pencapaian tujuan (goal attainment) merupakan sebuah sistem wajib menerangkan dan menyampaikan tujuan pokoknya. Goal yaitu sebuah sistem yang tidak boleh tidak mampu memastikan suatu arah dan tujuan tersebut harus dicapai sesuai dengan direncanakan. Melalui misi Allah dalam penciptaan tersebut merupakan misi yang umum (berlaku untuk semua orang atau untuk seluruh dunia) terhadap ciptaanNya dan Allah sendiri mempertalikan dirinya dengan dunia secara universal. Hal ini menerangkan tujuan pokoknya yaitu bahwa Allah dari

72 Prasetya, Nurdin, and Gunawan, "Perubahan Sosial Masyarakat Dalam Perspektif Sosiologi Talcott Parsons Di Era New Normal."

${ }^{73}$ Kirk, Apa Itu Misi? Suatu Penelusuran Teologis.

${ }^{74}$ Albet Saragih and Johanes Waldes Hasugian, "Model Asuhan Keluarga Kristen Di Masa Pandemi Covid-19," Jurnal Teruna Bhakti 3, no. 1 (2020): 1.

75 Tri Rejeki Andayani, “Sumber Informasi Serta Dampak Penerapan Pembatasan Sosial Dan Fisik Pada Masa Pandemi \{COVID\}-19: \{Studi\} Eksploratif Di \{Indonesia\}," Jurnal Psikologi Sosial (2020), http://jps.ui.ac.id/index.php/jps/article/view/229. 
awalnya berhubungan dengan manusia dalam arti umum (berlaku untuk semua orang atau untuk seluruh dunia) yakni manusia (dari segala bangsa dan bukan istimewa misalnya, Israel saja). Dalam konteks masa kini, penggunaan nyanyian rohani diciptakan sesuai dengan perkembangan dan kebutuhan jemaat pada bagian bahasa. Bagian ini menerangkan kesegambaran manusia dengan Allah (imago Dei) yang berada dalam kesadaran atau dalam akal budi (pikiran) pada manusia yang memiliki keterkaitan dengan budaya di sekitarnya. Salah satu bentuk ciptaan dari jemaat GKE Hosianna di Palangka Raya yaitu adanya penggunaan bahasa Dayak Ngaju dan buku Nyanyin Ungkup dalam liturgi ibadah yang dihadiri tidak saja dari generasi tua, tetapi generasi muda juga. Oleh karena situasi pandemi global ini, maka penggunaan liturgi bentuk ke II dalam bahasa Dayak Ngaju dan Nyanyin Ungkup belum dapat dilaksanakan untuk sementara waktu. Motif yang dilakukan oleh GKE Hosiana ini demi menerapkan protokol kesehatan. Dengan demikian, GKE Hosianna turut serta terilbat dalam pencegahan penyebaran covid-19 dan dapat hidup dengan sehat.

Ketiga, integrasi (integration) merupakan sebuah sistem patut menata antar relasi bagian-bagian yang menjadi unsurnya. Sistem ini juga harus menjalankan antar hubungan ketiga fungsi penting lainnya. Tahap integration nampak dari penerimaan kelompok biasa terhadap kelompok penulis yang mempunyai pengaruh sangat menentukan bagi karya-karya literatur atau sastra. Hal ini berkaitan para penulis bekerja kepada para penguasa yang tidak pelajar (Palestina purba) seperti para imam, dan orang-orang terpelajar. ${ }^{76}$ Dengan mengingat dan memahami bahwa literatur pada masa dahulu (dunia purba) merupakan suatu hasil karya bidang sastra yang sangat langka, sulit, tidak tersebar secara luas, dan terbatas dari satu komunitas sosial yang eksklusif. ${ }^{77}$ Berdasarkan hal lain, integration merupakan tahap jemaat (baik yang tua, maupun yang muda) diarahkan untuk melakukan kegiatan atau usaha yang dilakukan oleh jemaat itu sendiri untuk melestarikan bahasa daerah sebagai warisan budaya Dayak dengan menghadiri ibadah dalam liturgi jemaat Gereja Hosianna bentuk ke II (kutak Dayak Ngaju) yang menggunakan Nyanyin Ungkup. Selain itu, unsur integrasi itu penting, karena satu sama lain saling berpengaruh pada aturan yang telah dibuat aturan oleh pemerintah, maka GKE Hosianna sebagai bagian dari masyarakat Kalimantan Tengah harus mematuhi aturan protokol kesehatan. Apabila belum ada integrasi, maka protokol kesehatan ini belum berjalan sesuai dengan harapan dan hidup sehatpun akan terancam gagal.

Keempat, latensi atau pemeliharaan pola (latency) merupakan sebuah sistem menambah sesuatu yang kurang supaya menjadi lengkap, melindungi, menjadikan lebih berguna, baik motivasi individu maupun pola-pola kultural yang menciptakan dan menopang motivasi. Latency merupakan suatu tahapan bahwa GKE Hosianna patut memegang teguh nilai dasar dan norma yang telah dianut bersama yaitu mematuhi aturan protokol kesehatan yang telah dibuat oleh pemerintah untuk mengurangi peningkatan penyebaran covid-19. Setelah mencapai tujuan New Normal maka komponen masyarakat saling menjaga nilai dan norma baru yang

${ }^{76}$ Ord, In the Beginning: Creation and the Priestly History,

77 Ord, The Bible's First History: From Eden to the Court of David with the Yahwist. 
telah terbentuk. Mempertahankan kedisiplinan ini diharapkan akan menjadi budaya baru di masyarakat. Dengan demikian, misi penginjilan dapat tercapai dengan menggunakan tahapan kontekstualisasi berdasarkan realitas yang terjadi di jemaat.

\section{Rekomendasi untuk Penelitian Lanjutan}

Tulisan ini hanya menyajikan misi penginjilan pada masa penciptaan dalam teks Alkitab Kejadian 1 dan misi penginjilan pada masa pandemi covid-19, khususnya di GKE Hosianna Palangka Raya. Rekomendasi untuk penelitian selanjutnya masih terbuka dengan melihat misi penginjilan dari konteks yang lainnya yang belum tersentuh dalam tulisan ini. Selain itu, rekomendasi untuk sinode GKE agar membuat strategi penginjilan yang lebih inovatif dalam menyikapi masa pandemi covid-19 dan setelah masa pandemi covid-19.

\section{Kesimpulan}

Berdasarkan uraian di atas, maka dapat disimpulkan bahwa misi penginjilan telah terjadi mulai dari masa penciptaan hingga masa kini Misi penginjilan pada masa penciptaan dalam teks Alkitab Kejadian 1 dan misi penginjilan pada masa pandemi covid-19, yang pada masing-masing kedua konteks tersebut memiliki kebudayaan yang berwarna-warni yang turut serta mempengaruhi misi penginjilan. Dalam teks Kejadian 1 masa penciptaan diwarnai penyampaiannya dari bahasa Ibrani dan pemikiran Yunani yang pada akhirnya mempunyai pengaruh dalam memberi ketentuan yang amat tersampaikan akan tujuan Tuhan kepada umatnya. Sebab para penulis Alkitab menggunakan kebudayaan untuk mengkomunikasikan cerita atau keterangan mengenai kejadian atau peristiwa itu. Dengan demikian, ada bermacam-macam pendekatan yang digunakan sesuai dengan keperluan dan konteks keadaan warganya, baik dari pada masa penciptaan maupun pada masa pandemi covid-19 melalui tahapan kontekstual, sehingga misi penginjilanpun dapat tercapai.

Dalam situasi pandemi covid-19, jemaat GKE Hosianna menerima dampak negatif maupun dampak positif. Dampak negatifnya yaitu memang sebelum masa pandemi covid-19 ini, penggunaan liturgi bahasa Dayak Ngaju sudah terpinggirkan dengan hadirnya nyanyian rohani berbahasa Indonesia yaitu buku Nyanyian Kidung Baru (NKB) dan Pelengkap Kidung Baru (PKB), serta adanya pengaruh globalisasi. Kemudian pada masa pandemi covid-19, ruang dan waktu jemaat GKE Hosianna Palangka Raya semakin menjadi terbatas dan terpinggirkan dalam penggunaan liturgi bahasa Dayak Ngaju baik dalam persiapan pelaksanaan maupun dari umat Tuhan yang melaksanakan pelayanannya. Sebab pelaksanaan ibadah hari Minggu menggunakan liturgi kebaktian Hari Minggu dalam bahasa Indonesia secara online atau virtual. Adapun dampak positif dari misi penginjilan selama pandemi ini yaitu nampak pada keikutsertaan jemaat GKE Hosianna untuk mengurangi peningkatan penyebaran covid-19 dengan memegang teguh nilai dasar dan norma yang telah dianut bersama yaitu mematuhi aturan protokol kesehatan (prokes) yang telah dibuat oleh pemerintah, sehingga jemaat Tuhan dapat dalam keadaan sehat. Kepatuhan akan aturan prokes tersebut menunjukkan tindakan rasional instrumental dan keteraturan secara mendalam berdasarkan harapan atas 
kepentingan atau tujuan dalam tindakan yang dilakukan sesuai konteks pandemi covid-19. Selain itu, hubungan antara anggota keluarga menjadi harmonis, karena anjuran untuk tinggal di rumah selama masa pandemi pasti saja menyebabkan peluang besar dan lebih lama berinteraksi bersama keluarga dibandingkan dengan masa sebelum pandemi COVID-19.

\section{Rujukan}

Andayani, Tri Rejeki. “Sumber Informasi Serta Dampak Penerapan Pembatasan Sosial Dan Fisik Pada Masa Pandemi \{COVID\}-19: \{Studi\} Eksploratif Di \{Indonesia\}." Jurnal Psikologi Sosial (2020). http://jps.ui.ac.id/index.php/jps/article/view/229.

Arisandie, Tio Pilus. "Potret Kekristenan Pada Suku Dayak Pesaguan Di Provinsi Kalimantan Barat." Jurnal Ilmiah Religiosity Entity Humanity (JIREH) 3, no. 1 (2021): 63-75.

Bakhri, Syamsul, and Alan Sigit Fibrianto. “Hubungan Kegiatan Ekstrakurikuler Pramuka Dengan Tingkat Religiusitas Siswa Sma Negeri 1 Tangen (Perspektif Teori Sistem Sosial Talcott Parsons)." Jurnal Sosiologi Agama 12, no. 1 (2018): 67.

Bunu, Helmuth Y. Metodologi Penelitian. Edited by Eddy Lion Muhammad Basrowi, Suwandi, Soenyono. I. Surabaya: Jenggala Pustaka Utama, 2015.

Christian, Firman, and Robi Panggarra. "Makna Kata Ekklesia Berdasarkan Matius 16:18 Dan Implementasinya Dalam Kehidupan Orang Percaya Masa Kini." Jurnal Jaffray 9, no. 2 (2011): 90.

Edo Johan Pratama, Siti Rochani, Nurhadi. “Solo Belajar Community Learning Tutoring For Sumber Tapen Residents Learn (Phenomenological Study In Rt 02 Rw 03 Sumber Tapen, Banjarsari, Surakarta)." SOSIALITAS; Jurnal Ilmiah Pend. Sos Ant 8, no. 1 (2017). https://jurnal.fkip.uns.ac.id/index.php/sosant/article/view/12031.

Elly M. Setiadi, H. Kama A. Hakam, dan Ridwan Effendi. Ilmu Sosial Dan Budaya Dasar. 8th ed. Jakarta: Prenada Media Group, 2012.

Ferdinan, Bherton. "Peranan Gembala Dan Strategi Penggembalaan Dalam Meningkatkan Pembinaan Jemaat." STELLA: Jurnal Teologi dan Pendidikan Kristen 1, no. 1 (2021): 45-56.

GKE), Yayasan Musik Gerejawi Gereja Kalimantan Evangelis (YAMUGER. Nyanyin Ungkup Empat Suara (SATB). iii. Palangka Raya: YAMUGER GKE, 2006.

Gunawan, Fahmi, Stain Sultan, Qaimuddin Jl, Sultan Qaimuddin No, Baruga Kendari, and Sulawesi Tenggara. "Bahasa Alay: Refleksi Sebuah Budaya." Jurnal Bahasa dan Sastra 10, no. 2 (2011). http://202.0.92.5/adab/Adabiyyat/article/view/735.

Johnson, Doyle Paul. Sociological Theory Classical and Contemporary Perspectives. Jakarta: Gramedia, 1986.

Kirk, J. Andrew. Apa Itu Misi? Suatu Penelusuran Teologis. Jakarta: Gunung Mulia, 2012.

Kosmanto, Kokos. "Strategi Penginjilan Kontekstualisasiterhadap Kebudayaan Gawai Dayak Bakati Di Kiung" (2020).

Kriswanto, Agus. "Tohu Wabohu Dan Creatio Ex Nihilo: Tafsir Kejadian 1:1-2 
Sebagai Perspektif Memahami Realitas Anomali." Mitra Sriwijaya: Jurnal

Teologi dan Pendidikan Kristen 1, no. 1 (2020): 1-3.

Kustoyo, Nerrisa Erviana Hadianti, and Siti Zunariyah. "Pemaknaan Mahasiswa

Terhadap Simbol Pancasila Sebagai Identitas Bangsa." Journal of Development and Social Change 2, no. 2 (2020): 3.

Lambut, Melkiannus Paul. “Narasi Kesejarahan Perjuangan Tanpa Henti Gereja Kalimantan Evangelis Sejak Cikalbakal 1835 Hingga Kini." Jurnal Pambelum:

Teologi Kontekstual 5, no. 2 (2015). https:/ / stt-gke.ac.id/wpcontent/uploads/2020/08/Volume-5-Nomor-2-Desember-2015.pdf.

Lempp, Walter. Tafsiran Alkitab Kejadian (1:1-4:26). Keempat. Jakarta: Gunung Mulia, 1987.

Mahin, Marko. 70 Tahun GKE: Pergumulan Dan Upaya GKE Menuju Kemandirian.

Banjarmasin: Majelis Sinode Gereja Kalimantan Evangelis, 2005.

Manurung, Kosma. “Taurat Dan Nubuat Palsu: Kajian Sudut Pandang Taurat

Terhadap Nubuat Palsu." Jurnal Teologi Berita Hidup 2, no. 2 (2020).

https:/ / www.e-journal.sttberitahidup.ac.id/index.php/jbh/article/view/31.

Marsudi, Marsudi, and Siti Zahrok. "Kesetiaan Berbahasa Indonesia Dipertanyakan

Di Era Globalisasi." Jurnal Sosial Humaniora 8, no. 1 (2015): 95.

Marsunu, Y.M. Seto. Allah Leluhur Kami: Tema-Tema Teologis Taurat. Yogyakarta:

Kanisius, 2008.

Moleong, Lexy J. Metodologi Penelitian Kualitatif. 39th ed. Bandung: Remaja Rosdakarya, 2019.

Nurlatu, Jesly. “Kurangnya Penginjilan Pada Pertumbuhan Gereja Masa Kini.” Jurnal Strategi Pertumbuhan Gereja (2020).

Objantoro, Enggar. “Sejarah Dan Pemikiran Kaum Injili Di Tengah-Tengah

Perubahan Dan Tantangan Zaman." Evangelikal: Jurnal Teologi Injili dan

Pembinaan Warga Jemaat 1, no. 2 (2017): 129.

Ord, Robert B. Coote \& David Robert. In the Beginning: Creation and the Priestly History, . Mineapolis: Fortress Press, 1991.

- - - . The Bible's First History: From Eden to the Court of David with the Yahwist. Philadelphia: Fortress Press, 1989.

Pabbajah, Mustaqim, Nurhidayat Muhammad Said, Faisal, M. Taufiq Hidayat Pabbajah, Hasse Jubba, and Juhansar. "Deauthorization of the Religious Leader Role in Countering Covid- 19: Perceptions and Responses of Muslim Societies on the Ulama's Policies in Indonesia." International Journal of Criminology and Sociology 9, no. November (2020): 262-273.

Panjaitan, Firman, and Hendro Siburian. "Misi Kristologi Dalam Konteks Kebudayaan." Logia 1, no. 1 (2020): 44-61.

Paul F. Knitter. Satu Bumi Banyak Agama: Dialog Multiagama Dan Tanggung Jawab Global. 4th ed. Jakarta: Gunung Mulia, 2008.

Prakoso, Teguh. "Rasionalitas Like Di Sosial Media Siswa Sma Negeri 1 Teras, Boyolali." Sosialitas: Jurnal Ilmiah Pend. Sos Ant 5, no. 2 (2015). https://jurnal.fkip.uns.ac.id/index.php/sosant/article/view/10376.

Prasetya, Andina, Muhammad Fadhil Nurdin, and Wahju Gunawan. "Perubahan Sosial Masyarakat Dalam Perspektif Sosiologi Talcott Parsons Di Era New 
Normal." Sosietas Jurnal Pendidikan Sosiologi 11, no. 1 (2021): 929-939.

Prastu Heri Wibowo, Agus Mahfud Fauzi. “Rasionalitas Masyarakat Memilih Calon

Bupati Milenial Di Kalangan Sesepuh Desa Sumberbening Kecamatan Dongko

Kabupaten Trenggalek." Jurnal Ilmu Politik dan Pemerintahan 7, no. 1 (2021).

http://jurnal.unsil.ac.id/index.php/jipp/article/view/2938.

Ristyawati, Aprista. “Efektifitas Kebijakan Pembatasan Sosial Berskala Besar Dalam

Masa Pandemi Corona Virus 2019 Oleh Pemerintah Sesuai Amanat UUD NRI

Tahun 1945." Administrative Law and Governance Journal 3, no. 2 (2020): 240-

249.

Rosang, Djonly J. R. “Studi Kritik Teori Penciptaan Dalam Kejadian 1:1-2 (Suatu

Kajian Terhadap Argumentasi Teori Celah)." HUPERETES: Jurnal Teologi dan

Pendidikan Kristen 1, no. 1 (2019): 62-78.

Saragih, Albet, and Johanes Waldes Hasugian. "Model Asuhan Keluarga Kristen Di

Masa Pandemi Covid-19." Jurnal Teruna Bhakti 3, no. 1 (2020): 1.

Setiawan, David Eko. "Menjembatani Injil Dan Budaya Dalam Misi Melalui Metode

Kontektualisasi." Fidei: Jurnal Teologi Sistematika dan Praktika 3, no. 2 (2020):

160-180.

Sihombing, Bernike. “Studi Penciptaan Menurut Kitab Kejadian 1 : 1-31." Jurnal

Kurios: Jurnal Teologi dan Pendidikan Agama Kristen 1, no. 1 (2013): 1-31.

https://www.sttpb.ac.id/e-journal/index.php/kurios/article/view/15.

Sontoso, Widjajanti Mulyona. Ilmu Sosial Di Indonesia: Perkembangan Dan Tantangan.

Edited by Santoso. Jakarta: Yayasan Pustaka Obor Indonesia, 2016.

Sugiono, Panjhi. "Pendekatan Penginjilan Kontekstual Paulus Berdasarkan Kisah

Para Rasul 17:16-34." Jurnal Ilmu Teologi dan Pendidikan Agama Kristen 1, no. 2 (2020): 87.

Telhalia, Telhalia. “Teologi Kontekstual Pelaksanaan Jalan Hadat Perkawinan Dayak Ngaju Di Gereja Kalimantan Evangelis (GKE)." Religió: Jurnal Studi Agamaagama 6, no. 2 (2016): 230-252.

W. S. LaSor, D.A. Hubbars dan F.W. Bush. Pengantar Perjanjian Lama 1: Taurat Dan Sejarah. 17th ed. Jakarta: Gunung Mulia, 2012.

Wibowo, Markus. "Peranan Musik Gereja Dalam Pembentukan Karakter Jemaat Dan

Pembawa Misi Gereja Di Gereja Bethany Indonesia Menara Doa

Melonguane." PSALMOZ A Journal of Creative and Study of Church Music 1

(2020): 1-14. http://ejournal-iakn-

manado.ac.id/index.php/psalmoz/article/view/192/192.

Yakob Tomatala. Penginjilan Masa Kini Jilid 2. Kedua. Malang: Gandum Mas, n.d.

Yuono, Yusup Rogo. “Etika Lingkungan : Melawan Etika Lingkungan

Antroposentris Melalui Interpretasi Teologi Penciptaan Yang Tepat Sebagai Landasan Bagi Pengelolaan-Pelestarian Lingkungan." FIDEI: Jurnal Teologi Sistematika dan Praktika 2, no. 1 (2019): 183-203. 